\title{
Extending An Accounting Information System Learning Aid To Firm Valuation
}

Keith Stanga, (kstanga@utk.edu), University of Tennessee

Jon Woodroof, (jwoodroof@utk.edu), University of Tennessee

\begin{abstract}
This article reports a case on firm valuation. Students are required to determine the fair market value of a company's stockholders' equity by projecting the company's earnings and then discounting the projected earnings to a present value. The case extends an earlier case on the accounting information system and allows students to visualize the effects of future earnings and cost of capital on firm valuation. Student perceptions of the case were very favorable.
\end{abstract}

\section{Introduction}

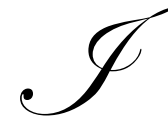

$\mathrm{n}$ the summer 2001 issue of this journal, Stanga and Woodroof reported a new learning aid to the accounting information system---the Jay Company Accounting Information System Case. ${ }^{1}$ The aid focuses on a three-period case for a hypothetical enterprise called the Jay Company. Students solve the case in a spreadsheet environment that allows them to readily observe the flow of information from journals to ledgers to financial statements. With only 20 relatively straightforward transactions, the Jay Company is formed, operated for three years, and then dissolved. The case is limited to 20 transactions to help students to focus on the big picture of accounting and to minimize their natural tendency to get mired in details. After each of the three periods, students are required to prepare the four basic financial statements (income statement, balance sheet, statement of cash flows, and statement of retained earnings) under both accrual-basis and cash-basis accounting.

The case also introduces students to a balance sheet grid that offers an innovative way for them to quickly observe the financial statement effects of business transactions in a single location. Overall, the Jay Company Accounting Information System Case offers several improvements to the typical textbook problem that is used to illustrate the accounting information system.

The objective of this article is to extend the Jay Company case to the issue of firm valuation.

\section{Rationale for an Extension into Firm Valuation}

The Jay Company Accounting Information System Case focuses on past information and requires students to prepare historical financial statements. Among other insights, the statements reveal the book (or accounting) value of Jay Company's stockholders' equity at the end of 1998, 1999, and 2000. Like the financial statements for real companies, Jay Company's financial statements do not indicate the firm's actual worth in the marketplace (i.e., fair market value) at any point in time. Determining the fair market value of a firm's stockholders' equity is a very important objective of many users of financial statements. In fact, it is a major reason why many users (particularly investors, potential investors, and financial analysts) regard financial statements as useful.

One of the most important accounting metrics shown in Jay Company's financial statements is net income. Using past net incomes and other information about the company, its industry, and the economy, users of financial statements can make better predictions about future net incomes, and ultimately, better predictions of net cash flows that the firm will generate. These future cash flows are what give value to the firm at any point in time. The price

Readers with comments or questions are encouraged to contact the authors via email. 
that investors would be willing to pay for the firm is largely determined by the amount and timing of the future cash flows.

To encourage students to develop a forward-thinking mentality and to integrate accounting, finance, and information systems, we developed an extension of the Jay Company case. Our aim was to develop a case that would be targeted primarily toward upper-division business school students. The case focuses on the "big picture" of firm valuation and, for reasons of clarity and simplicity, assumes away some details that would be required in a real company valuation. In the extension case, the Jay Company Valuation Case, students are required to determine the fair market value of the company's stockholders' equity by projecting the company's earnings and then discounting the projected earnings to a present value as of a specified valuation date. By working this case, students are able to clearly observe the role that future earnings play in firm valuation in a relatively straightforward manner. The resulting graph allows students to observe the impact on firm value of various growth rates and weighted average costs of capital. To introduce a greater "real world" flavor to the case, students are also required to discuss the factors that they believe should be considered in determining expected growth rates for a real company selected from the Fortune 1000.

For simplicity, this article uses the same historical dates and amounts that are used in the Jay Company Accounting Information System Case. Obviously, the instructor could change the dates and/or amounts to suit personal preferences.

The authors administered the case to 31 students (accounting and finance majors) enrolled in a junior-level, intermediate accounting course during spring semester 2002 at a large, comprehensive state university. Students worked on the case in teams of three or four persons. All students had previously completed the Jay Company Accounting Information System Case during the first two weeks of the semester.

After submitting the valuation case solutions, students completed a questionnaire designed to discover the learning benefits of the case. As explained later, the students' perceptions of the case were very favorable.

\section{The Jay Company Valuation Case}

The text of the Jay Company Valuation Case appears below:

The Jay Company Information System case allows you to practice the accounting and financial reporting for a company that began and ended its existence during a three-year period $(1998,1999$, and 2000). In the special case of Jay Company, investors knew for certain how much cash they paid into the company when it started in 1998 and how much cash the company paid back to them when the company liquidated in 2000 . Of course, companies do not ordinarily liquidate after only three years, and many remain in business for very long periods of time.

For companies that remain in business for many years, a need frequently exists to determine the value of the business (i.e., the value of the company's stockholders' equity) prior to liquidation. For publicly held companies, such as Microsoft, Exxon Mobil, or Pfizer, the stock market gives important day-to-day information about the value of the business. But even in those cases, stock market prices only indicate the amount for which a relatively small number of shares could be traded. The question of how much the entire company is worth cannot be determined simply by multiplying the market price by the number of shares outstanding. Microsoft, for example, has more than 5 billion shares of common stock outstanding. If all shares were sold at one time (highly unlikely), the price would not likely be the same as the market price per share in the stock market.

Determining the value of a privately held business is even more challenging. How does an investor determine how much the stockholders' equity is worth when a company has no public market price to at least help guide the way?

To value a firm, we must recognize that investors ordinarily invest cash in a business. What they want to know is how much cash they will get back and when they will get it. Because net income under accrual basis accounting 
provides a reasonable estimate of a company's sustainable future cash flows, generally accepted accounting principles require companies to use the accrual basis of accounting. Not surprisingly, investors focus heavily on net income (and related earnings per share) when making their cash flow predictions, and that is why net income is such an important accounting measurement. Virtually all businesses seek growth in net income over time.

To derive a market value for virtually any business, sophisticated investors begin by examining and analyzing the company's financial statements. They attempt to predict the company's future net incomes---year by year---at some reasonable and sustainable growth rate (Sophisticated investors also try to estimate the firm's termination value, but for simplicity, you may ignore this in your analysis.). Then they discount those future net incomes to the present value (i.e., the firm's value at the valuation date) by using a discount rate that indicates the investors' required rates of return. This discount rate should reflect the cost of the capital that the firm invests to generate the future net income stream. This discount rate, which considers both the cost of debt financing and the cost of equity financing, is known as the weighted-average cost of capital (WACC). You typically learn how to compute the WACC in your financial management courses.

For purposes of this case, assume that all information for Jay Company for the years 1998 and 1999 remains the same (e.g., net income for 1999 is still \$94,000), while all information after 1999 changes. Assume that instead of liquidating in 2000, Jay Company plans to continue operations into the future. While the company does not know for certain how long it will be in business, Jay Company expects to be in business for 20 years after 1999 .

\section{Instructions}

1. Determine the value of the Jay Company firm (i.e., the market value of Jay Company's stockholders' equity) as of the end of 1999 at projected net income growth rates of $0 \%, 10 \%, 20 \%, 30 \%, 40 \%$, and $50 \%$. Also, for each net income growth rate, assume that Jay Company's WACC is (1) $10 \%$, (2) $12 \%$, and (3) $15 \%$.

\section{Deliverables}

a. Excel spreadsheet template used to calculate the value of Jay Company at each net income growth rate and WACC.

b. $\quad$ Graph of your findings.

c. Brief synopsis of your findings.

2. In part 1 above, expected growth rates for Jay Company's net income were provided to you. If you were estimating the value of stockholders' equity for a real company, you would need to formulate your own earnings growth rate for the company.

Go to Fortune.com on the Internet and find the list of Fortune's 1000 largest industrial companies. Choose a real company on the Fortune list and assume the role of a financial analyst trying to estimate the value of the company's stockholders' equity.

\section{Deliverable}

Write a formal business memorandum that does not exceed one page, typed and single-spaced, in length. Your memo should explain the major factors that you would consider when determining your own earnings growth rate estimate for your company. You do not have to do an actual valuation for the company that you select. You should write your memo using proper English. Be sure to edit your memo very carefully before submitting it. 


\section{Student Deliverables}

\subsection{Spreadsheets}

The following materials (Figures 1a-1f and Figure 2) illustrate and lead you through the building of a spreadsheet template that supports the valuation analysis of Jay Company. This is an example of the student deliverables that you might expect for Part 1 of the case.

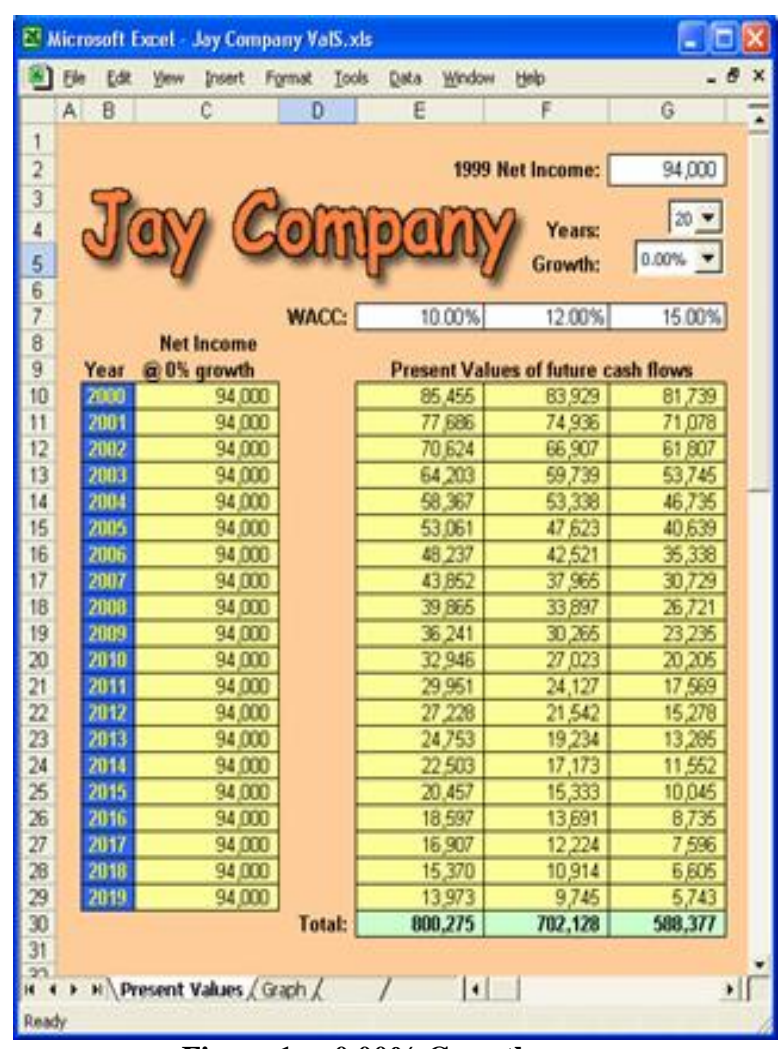

Figure 1a: $0.00 \%$ Growth

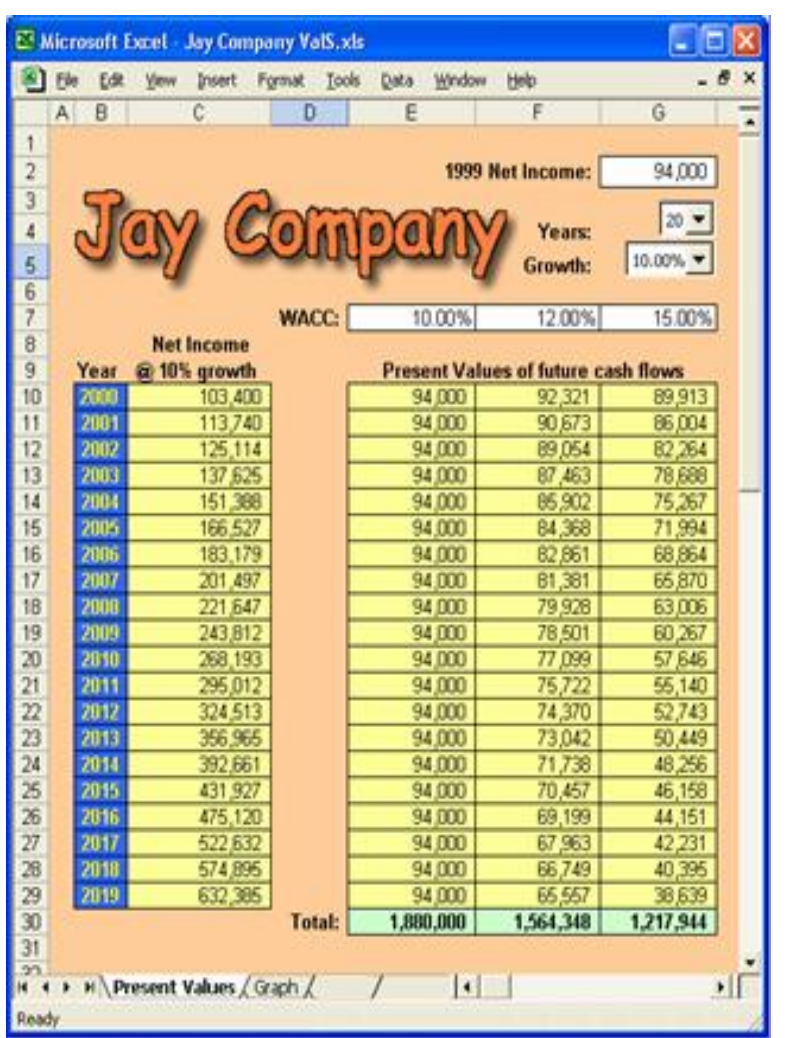

Figure 1b: $10.00 \%$ Growth 


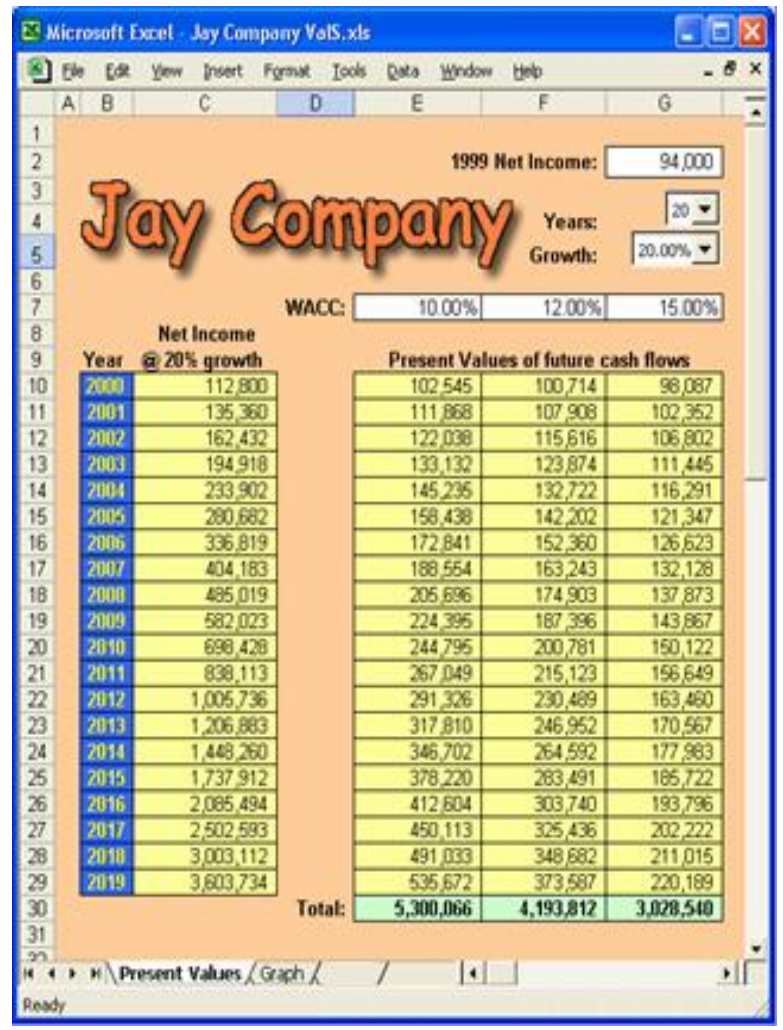

Figure 1c: $20.00 \%$ Growth

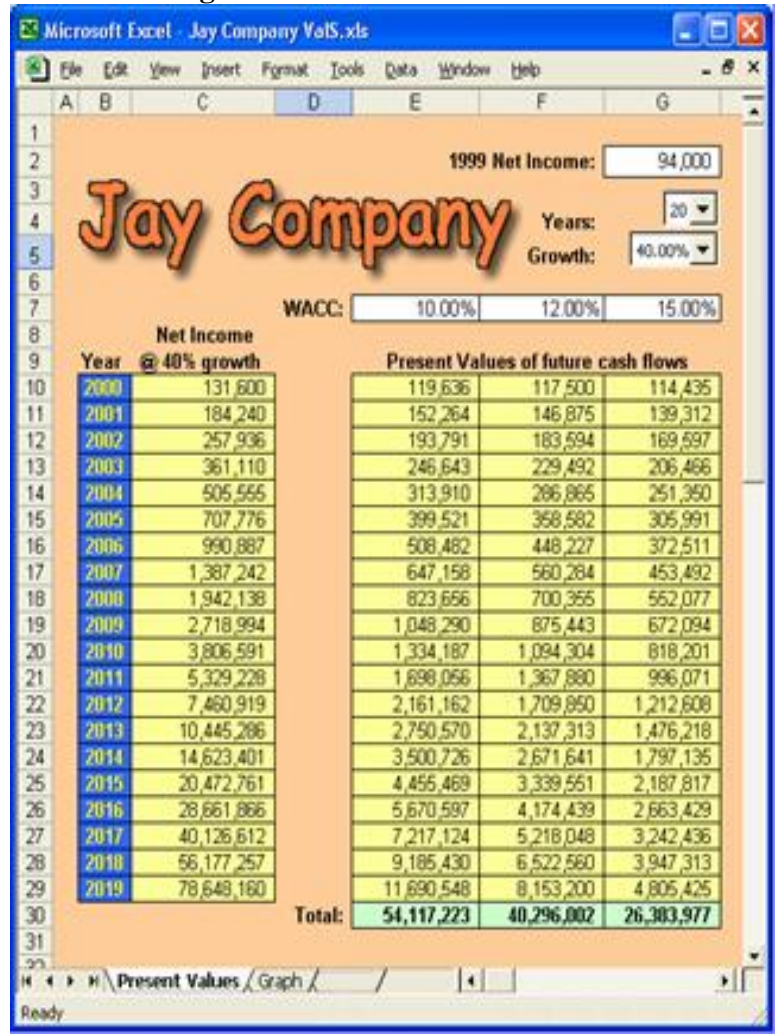

Figure 1e: $40.00 \%$ Growth

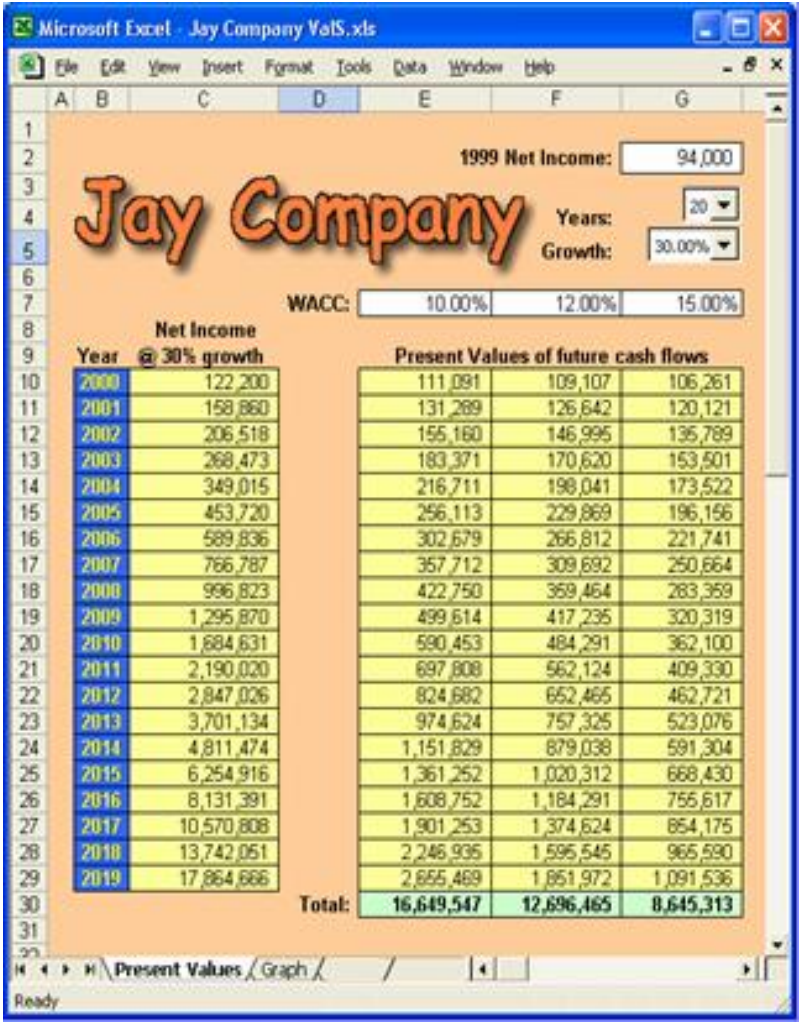

Figure 1d: $30.00 \%$ Growth

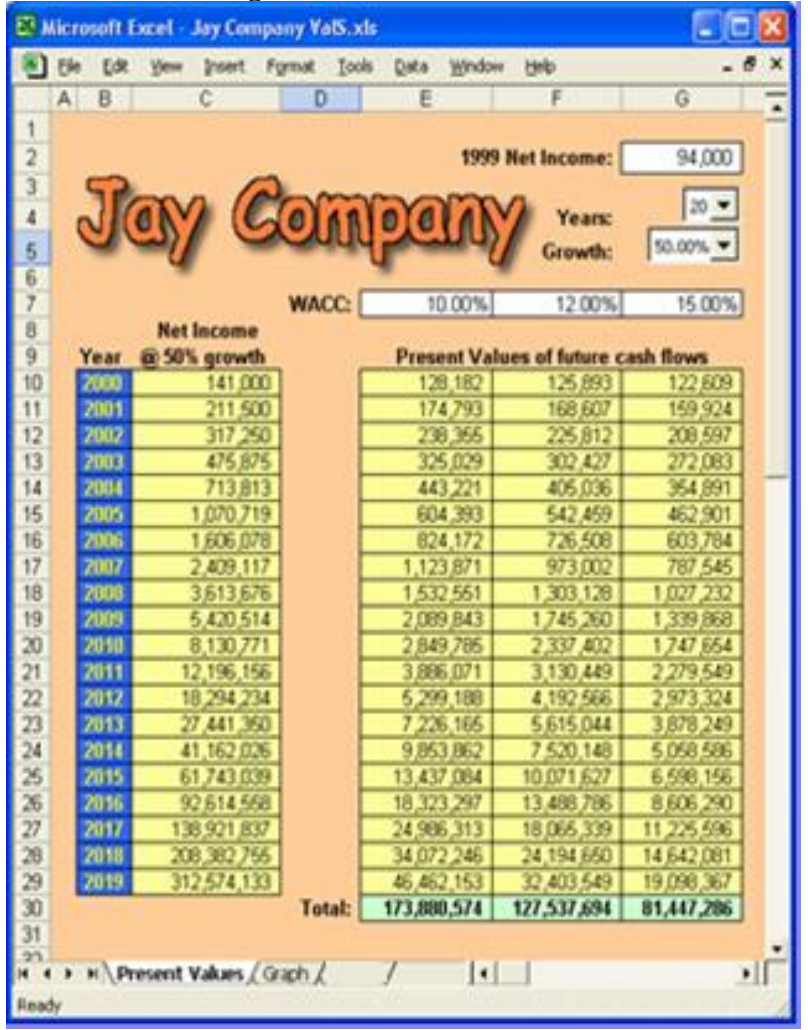

Figure 1f: $50.00 \%$ Growth 


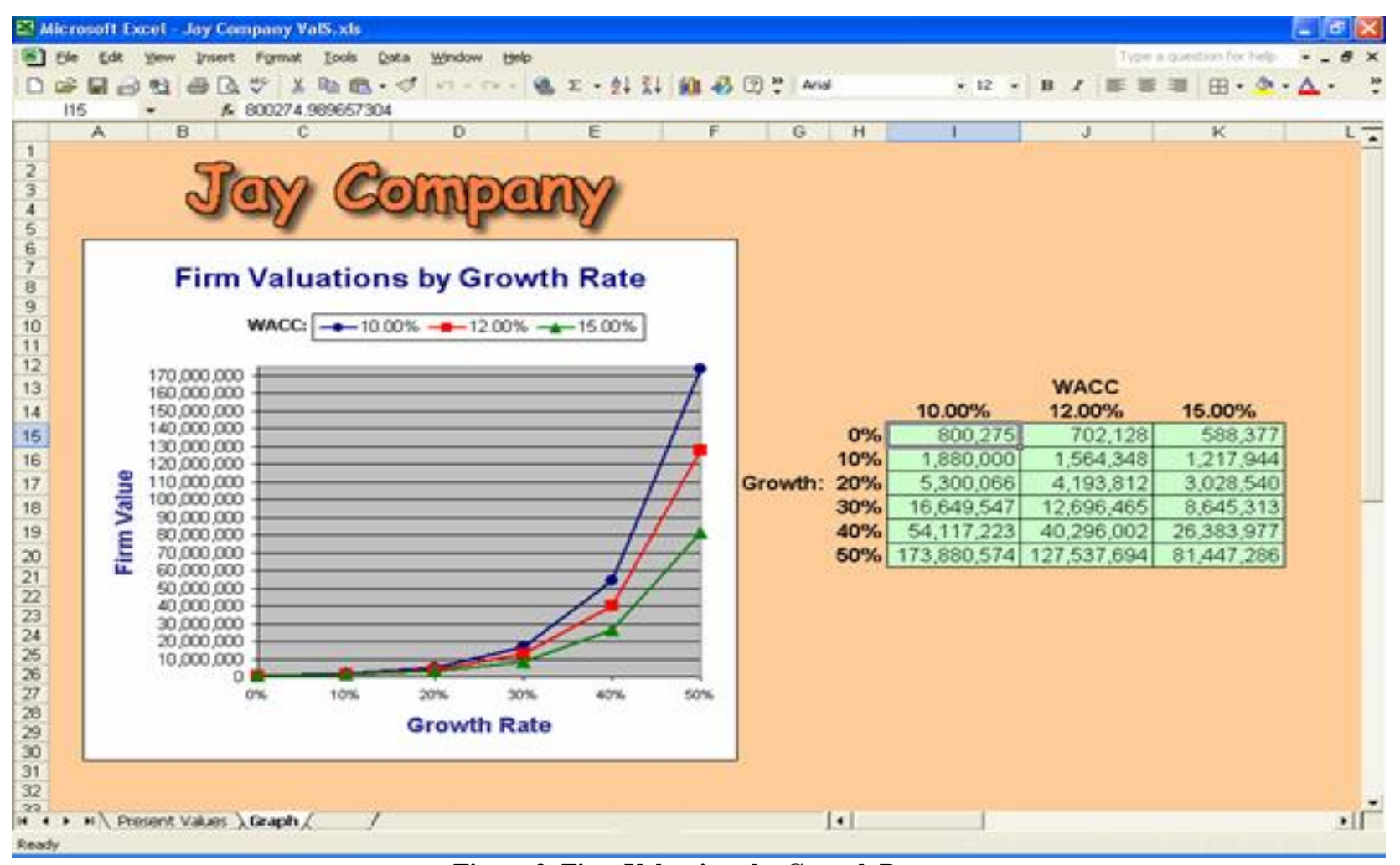

Figure 2: Firm Valuations by Growth Rate

This valuation template is fairly straight-forward to build in a spreadsheet, and students should be able to complete it in a reasonable amount of time. The template requires two worksheet pages, three functions, and six cells that are used for parameter inputs.

Let's start with the parameters. Students should first create two worksheet pages called "Present Values" and "Graph". On the Present Value page (refer to Figures 1a-1f), students enter the 1999 net income, the number of years representing the expected life of the company, a net income growth rate, and three discount rates (WACCs). In cell G2, enter Jay Company's net income for 1999. In the Jay Company Accounting Information Systems Case, $\$ 94,000$ is the correct accrual basis net income for 1999 . Thus $\$ 94,000$ is the correct starting point for the calculation of future net incomes.

1. In cell G4, enter the number of years Jay Company expects to be in business.

2. In cell G5, enter the net income growth rate.

3. In cell $\mathrm{E} 7$, enter the $1^{\text {st }}$ discount rate.

4. In cell F7, enter the $2^{\text {nd }}$ discount rate.

5. In cell G7, enter the $3^{\text {rd }}$ discount rate.

Next, let's look at the formulas that drive the firm valuation calculations. First, create a formula in cell C10 that will increase net income at the desired rate. In cell $\mathrm{C} 10$, type $=\mathrm{G} 2 *(1+\$ \mathrm{G} \$ 5)$. G2 is the initial net income for Jay Company, and G5 is the growth rate. Once this has been entered correctly (take special care to enter the "\$" before the column and row - this identifies an absolute address), it can be copied down to the remaining rows, each row representing the corresponding year in the expected life of the company.

Next, create a formula in cell E10 that will calculate the present value of the net income for that year. In cell $\mathrm{E} 10$, type $=\$ \mathrm{C} 10 /(1+\mathrm{E} \$ 7)^{\wedge} \mathrm{ROW}(\mathrm{A} 1)$. Let's look carefully at this formula. The cells in column $\mathrm{C}$ represent the net incomes corresponding the appropriate years in the expected life of the firm, adjusted for expected growth. So, 
C10 is the net income of Jay Company projected for the year 2000, increased at the growth rate entered in G5. The next part of the formula takes the net income adjusted for expected growth, and discounts it to present value using the appropriate discount rate (cell E7 is the first WACC of interest, 10\%). The formula does this by using the function, ROW().

ROW() returns the row associated with cell A1 (this is 1). The "^" is the power symbol. This raises the discount component of the formula to the $1^{\text {st }}$ power for the first year following the valuation year. Copying this formula to the next row will cause ROW() to equal 2, thus raising the discount component of the formula to the $2^{\text {nd }}$ power for the next year. Once you enter the formula into cell E10 (being careful to identify rows or columns as absolute using "\$"), cell E10 can then be copied into the entire range of E11 through G29. This creates the formulas that calculate the present values of the increasing annual incomes of Jay Company using the three discount rates.

The final formula sums the present values of the annual net incomes. In cell E30, type =SUM(E10:E29). This can then be copied to cells F30 and G30. The template is now ready for "what if" analysis where the impact of various growth rates on the present values of annual net incomes can be computed and compared.

Enter a growth rate of $0 \%$. Now highlight the totals of the present values of the annual net incomes (cells E30-G30), and copy. Click on the Graph page (refer to Figure 2) and paste the values (Edit, Paste Special, Values) into cell I15. Repeat this process for growth rates of 10\%, 20\%, 30\%, 40\%, and 50\%, copying the resulting totals of the present values of the annual net incomes from the Present Value page (cells E30-G30) and pasting these values into the Graph page cells I16, I17, I18, I19 and I20, respectively.

Finally, create an XY graph using the values that have been compiled in the table in cells H14-K20 on the Graph page.

\subsection{Synopsis of Findings}

In writing a brief synopsis of their findings, students should observe from the tables that positive growth rates cause net incomes to increase exponentially. Thus, the net income growth rate has a substantial and positive impact on firm value. Moreover, students should observe that the lower the WACC, the higher the firm valuation. Thus, a company has a strong, continuing incentive to lower its cost of capital. For the growth rates and WACCs used in this case, the graph shows that firm value increases noticeably when the growth rate reaches about 20 percent, and even more noticeably at rates greater than 20 percent. After reflecting on the graph, students should better understand why a company's stock price usually falls when the company is unable to sustain its earnings growth or when its cost of capital rises.

\subsection{Memorandum}

The case requires each student team to select a real company from the Fortune 1000 and write a formal business memorandum that explains the major factors that they would consider when formulating their own earnings growth rate estimate for the company. This exercise allows the students to think about the valuation of a real-world enterprise without having to do all of the fairly complex analysis that such a valuation would require. Recall that the Jay Company valuation case is aimed mainly at upper division undergraduate students. We believe that a comprehensive case that requires a complete valuation of a real company would be best aimed at students in graduate-level accounting or finance courses.

Of course, the instructor should anticipate that the precise content of the business memoranda will differ between the various student groups. In general, though, each memorandum should reflect a consideration of such factors as the following:

- What are the prospects for the general economy?

- What are the prospects for the company's industry?

- In what type of business does the company engage?

- How does the company generate income? 
- Does the company appear to have a competent management team that is adequately informing stockholders about the company's financial performance and future prospects?

- How has the company performed historically compared to its competitors? What major information stands out in the company's historical financial statements?

- What is the company's vision for the future, and does it have the means to achieve that vision?

- What risks does the company face as it moves forward?

- $\quad$ How does the stock market value the company today? For example, a relatively high P/E ratio generally suggests that investors expect considerable growth in future EPS. Of course, investors may be incorrect in their assessment.

\section{Student Assessments of the Valuation Case}

After submitting their case solutions, all students enrolled in the course $(n=31)$ completed a questionnaire that was designed to determine their perceptions about the learning benefits of the case. As indicated in Table 1, approximately 90 percent of the students agreed that the case improved their understanding of the relationships between accounting and finance, and 81 percent agreed that it helped them improve their computer skills. Ninety-four percent felt that the case improved their understanding of how accounting information can be used to value a company. Ninety percent believed that the case is a useful educational activity for the course.

Eighty-seven percent of the students believed that a desirable feature of the case is that it represents an extension of an earlier case covered in the course, as opposed to a brand new case. Although the students reported mixed feelings toward working on group projects that involve business issues, the vast majority (77 percent) believed that their groups worked well together and that they benefited from working on this particular case as a member of a group, as opposed to working alone. Only a minority of the students would have preferred working on this particular case alone rather than as a member of a group.

On average, each student reported spending about three hours working on the case alone and four hours with other members of their group, for a total time commitment of seven hours. The overall results indicate that students believe that the valuation case is useful for the course and can be completed in a reasonable time period.

\section{Concluding Comments}

The Jay Company Accounting Information System Case focuses primarily on the past while the Jay Company Valuation Case focuses mainly on the future. Used together, the two cases can help students to better understand the accounting information system and how the system's output can help users to determine the value of the firm. The cases integrate important ideas from accounting, finance, and information systems and thereby help students to see across the "functional silos" that characterize many business schools. Assessment information gathered from students who solved the case was very encouraging, and we intend to keep using the case in the foreseeable future.

\section{Endnote}

1 Keith Stanga and Jon Woodroof, "The Jay Company Case: A New Learning Aid to the Accounting Information System, The Review of Business Information Systems, Volume 5, Number 3, Summer 2001, pp. 51-64. 
Table 1 Student Assessments of Jay Company Valuation Case (in percentages and rounded; $\mathbf{n = 3 1}$ )

\begin{tabular}{|c|l|c|c|c|c|c|}
\hline & \multicolumn{1}{|l}{$\begin{array}{c}\text { Strongly } \\
\text { Agree }\end{array}$} & Agree & Undecided & Disagree & $\begin{array}{c}\text { Strongly } \\
\text { Disagree }\end{array}$ \\
\hline 1 & $\begin{array}{l}\text { The case improved my understanding of certain } \\
\text { relationships between accounting and finance. }\end{array}$ & 9.7 & 80.7 & 6.4 & 3.2 & 0.0 \\
\hline 2 & $\begin{array}{l}\text { The case helped me to improve my computer } \\
\text { skills. }\end{array}$ & 9.7 & 71.0 & 6.4 & 12.9 & 0.0 \\
\hline 3 & $\begin{array}{l}\text { The case improved my understanding of how } \\
\text { accounting information can be used to deter- } \\
\text { mine the value of a company. }\end{array}$ & 6.4 & 87.1 & 6.4 & 0.0 & 0.0 \\
\hline 4 & $\begin{array}{l}\text { The case was a useful educational activity for } \\
\text { this course. }\end{array}$ & 6.4 & 83.9 & 6.4 & 3.2 & 0.0 \\
\hline 5 & $\begin{array}{l}\text { A desirable feature of the case is that it is an } \\
\text { extension of an earlier case that was covered in } \\
\text { the course. }\end{array}$ & 29.0 & 58.0 & 12.9 & 0.0 & 0.0 \\
\hline 6 & $\begin{array}{l}\text { In general, I like working on group projects that } \\
\text { involve business issues. }\end{array}$ & 9.7 & 41.9 & 19.3 & 22.6 & 6.4 \\
\hline 7 & $\begin{array}{l}\text { For this particular case, my group worked well } \\
\text { together. }\end{array}$ & 25.8 & 51.6 & 12.9 & 9.7 & 0.0 \\
\hline 8 & $\begin{array}{l}\text { I benefited from working as a member of a } \\
\text { group on this case, as opposed to working } \\
\text { alone. }\end{array}$ & 35.5 & 41.9 & 9.7 & 9.7 & 3.2 \\
\hline 9 & $\begin{array}{l}\text { I would have preferred working on this case by } \\
\text { myself instead of as a member of a group. }\end{array}$ & 6.4 & 19.4 & 6.4 & 41.9 & 25.8 \\
\hline
\end{tabular}


Notes 